\title{
Superior Rice Cultivation as a Sustainable Agricultural
}

\author{
Gunawan Cipto Harsono ${ }^{1 *}$, Moh. Ardani ${ }^{2}$, Sumiarjo Kiswondo ${ }^{3}$ \\ ${ }^{123}$ Universitas Moch. Sroedji Jember \\ ${ }^{*}$ Corresponding author: \\ Email:gunawanciptoharsono@gmail.com
}

\begin{abstract}
.
The purpose of this study was to determine the effect of variety and number of seeds on plant growth and yield in a sustainable agricultural cultivation system and to understand the interaction between variety and number of seeds on plant growth and yield in a sustainable agricultural cultivation system. This research design uses a qualitative approach, which is a research procedure and understanding based on a methodology that identifies a social phenomenon. This reseach study used the qualitative design. It is a constructivist paradigm in which reality is produced in context and social life, is exploratory, theory and development in the field, and depends more on data gathering in the field to expose the actual situation in the field. The result of this research were Analysis of the Interaction between Varieties and Number of Seeds on Rice Growth Using the Ciherang variety combined with the number of seeds 6 stems per clump, it is recommended to use the number of seeds 2 stems per clump when using the Mekongga variety. The second findings of this research were Rice Plants as Sustainable Agriculture via Cultivation and Conventional Approaches can be applied in a variety of agricultural areas throughout Indonesia. A business partnership through vertical consolidation is formed by using the appropriate business partnership strategy to encourage the development of agribusiness in rural areas.
\end{abstract}

Keywords: Superior seeds, Technological innovation and Sustainable Agricultural

\section{INTRODUCTION}

Rice is one of the food crops grown by the majority of the world's population. Rice (Oryza sativa L.) is grown on agricultural land divided into plots and surrounded by mounds (Galengan) that hold or channel air and provide adequate air for growth. Rice is a strategic commodity in economic, social, and political terms because it contributes to agricultural programs (Jumakir, 2015). Indonesia is well-known for its agriculture. The farm sector is essential to the country's economy. A Rice field is the main source of agricultural production. The island of Java is Indonesia's rice production center.

However, the area of fertile paddy fields on the island of Java experienced a decline in production due to the conversion of agricultural land to the non-agricultural sector which resulted in a rapid decline in rice production (Dewa K.S Swastika1, J. Wargiono2, Soejitno2, 2016).

Rice is high in carbohydrates, which are the primary source of energy in the human body. Rice is a staple food for the majority of Asians. Rice is not only an economic product for farming communities, but also a social commodity. Thus, the rice cultivation system that is built is not only concerned with its production but also its existence as a socio-cultural commodity (Thippeswamy, S., Chandramohan, Y., Madhavilatha, B., Pravalika, K., Zameema Samreen, Bhoomeshwar, K., Vinod, G. and Kalpana, 2014). The type of rice used has an impact on the success of the harvest. The species chosen must be an extraordinary species that is also fit for the land. It is hoped that local rice varieties will be replaced with more productive varieties. Given the significance of rice farming to Indonesia's 
food security. When we look at the situation in the field, it appears that farmers are less interested in utilizing certified superior seeds because they are more expensive.

Superior varieties are one of the technologies that make a real contribution to increasing rice yields. Superior varieties have contributed significantly to the increase in national rice production, as evidenced by the achievement of food self-sufficiency in 1984. One of the most important determining fulcrum points for increasing rice production is the development and enhancement of new better varieties (Zurriyati, 2016) Meanwhile (Putra Utama1, 2015), states that increasing productivity can be accomplished by using new superior varieties. With the application of innovative technology, the potential yield of lowland rice based on the adaptation of superior varieties used can reach 10 tons per ha.Rice fields in Indonesia are classified into several types, including Entisol, Inceptisol, Vertisol, Alfisol, Ultisol, and Histosol, which are common in Java, Bali, Lombok, Sumatra, Kalimantan, and Sulawesi (especially South Sulawesi). The source of the original material has a strong influence on the properties of the soil when irrigated. The diversity of the community's physical and social conditions has a significant impact on the pattern of rice cultivation and the technology used. As a result, the types of land use for rice in Indonesia are extremely diverse. High-quality rice varieties are still being produced; currently, more than 200 varieties have been developed through conventional breeding, which has been going on since the 1930s. However, the majority were created between the 1990s and the 2000s. It contains eight hybrid varieties that can be grown in a variety of agro-ecosystem conditions. The Ministry of Agriculture has released a total of 233 high-yielding rice varieties, including 144 inbred lowland rice high-yielding variations, 35 superior hybrid varieties, 30 upland rice varieties, and 24 tidal high-yielding variants, Research and Development in Agriculture (Delima Napitupulu and Lermansius, n.d.)

Based on previous research on the productivity of high-yielding rice varieties as sustainable cultivation, as explained above, is the background of research on the productivity of high-yielding rice varieties as sustainable cultivation, with references explaining that the use of short-lived high-yielding varieties is an option in the development of tidal land. Farmers rarely employ superior cultivars, such as the Kapuas type harvested on tidal land. Local varieties are planted on $90 \%$ of swamp land, according to estimates (Sulaiman and Imberan 2000). Farmers favor local varieties because of their ease of cultivation, low production inputs, high selling prices, and desirable rice qualities (Wahdah \& Langai, 2015) To stimulate rice production in tidal and lowland areas, high-yielding varieties of photo-period sensitive rice with high yield potential ( $>3 \mathrm{t} / \mathrm{ha}$ ) are required. Farmers immediately chose high-yielding varieties that were resistant to $\mathrm{Fe}$, low $\mathrm{pH}$, alert, brown leaf spot soil, rice flavor, and favored grain shape (Kustianto, 2009)There is a better probability of getting more varied offspring if the selected types have a wide (diverse) kinship. As a result, as part of sustainable agricultural cultivation, it is necessary to investigate the interaction between varieties and the number of seeds on the growth and yield of rice plants, as well as the effect of varieties on the growth and yield of rice plants. The purpose of this study was to determine the effect of variety and number of seeds on plant growth and yield in a sustainable agricultural cultivation system and to understand the interaction between variety and number of seeds on plant growth and yield in a sustainable agricultural cultivation system. 


\section{LITERATURE REVIEW}

One of the technological innovation breakthroughs that can increase rice productivity and farmers' income is theoretical evidence that explains the new superior varieties of rice (SVR). SVR is also the simplest technical innovation for farmers to embrace because it is both inexpensive and practical. Superior varieties are one of the technological components that play a real role in increasing agricultural product production and quality (Aristya \& Mada, 2019) Furthermore, (Abdullah \& Tjokrowidjojo, 2005) argue that lowland rice SVR should be developed in Indonesia because: 1) ricefield is the primary source of national rice production, SVR planting will improve farmers' productivity, yield, and income. 2) SVR is hybrid rice, seed production is easier and less expensive, and farmers can afford high-quality seeds. New innovations are needed to increase farmer productivity while also raising income through an integrated crop and resource management. Approach, which is in accordance with agricultural development that focuses more on improving income for farmers.

Rice seed is grain that is harvested with the intention of being used as a farming input. By achieving predefined standards, seed certification obtains field inspection and laboratory testing from the authorized agency. There are four types of certified seeds. Breeder Seed $=\mathrm{BS}=$ Core Seed is the first class, followed by Foundation Seed = FS. Prasekti (Prasekti, 2015).

Superior seeds are an important factor in rice production because superior seeds can increase yields by $15 \%$ when compared to inferior seeds (Senewe \& Alfons, 2011) The higher the quality of the seeds used in farming, the higher the level of production. The usage of superior varieties seeds contributes up to 56 percent of the rise in national rice production, while the interaction of superior varieties irrigation and fertilization on the rate of increase in rice production contributes up to 75 percent (Hasibuan et al., 2013).Farmers typically pass down their crops to their children or grandchildren from their parents or forefathers. It will be locked in conventional cultivation patterns if this is done without significant guidance and training, and rice output will be limited, if not declining .Land preparation, seed selection, seeding, planting, fertilizing, plant maintenance, harvesting, and post-harvesting are all aspects of rice cultivation (Intarti et al., 2020).

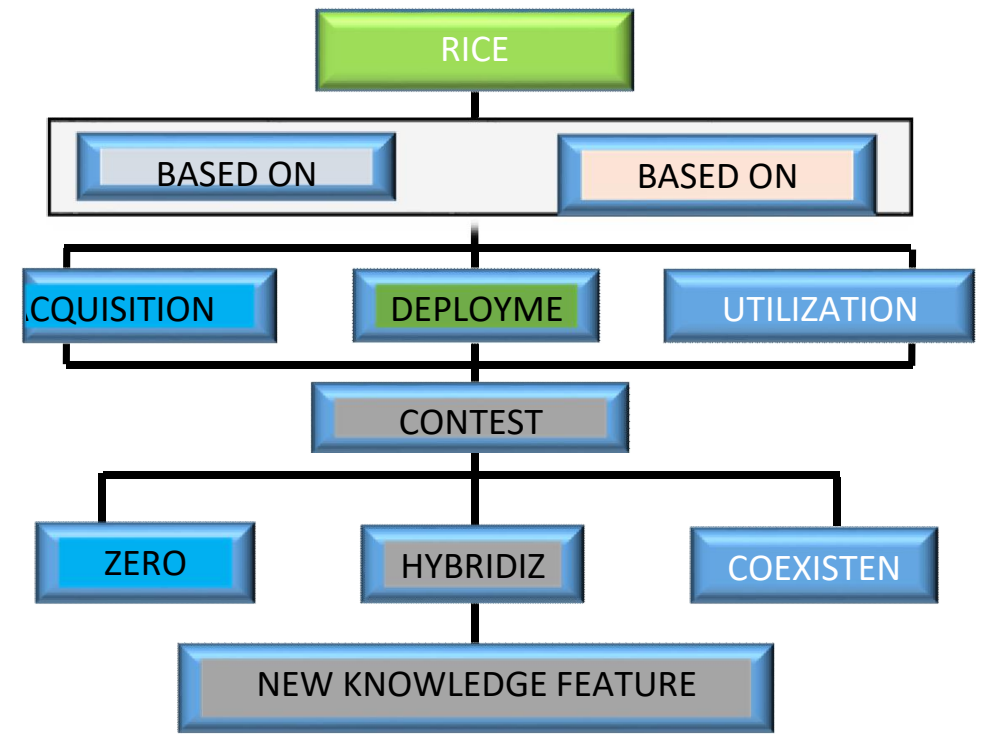

Fig 1. Rice Cultivation Knowledge Chart 


\section{METHODOLOGY}

This research design uses a qualitative approach, which is a research procedure and understanding based on a methodology that identifies a social phenomenon. The qualitative approach (Jajoo \& Malu, 2014) is a constructivist paradigm in which reality is produced in context and social life, is exploratory, theory and development in the field, and depends more on data gathering in the field to expose the actual situation in the field.

Qualitative research can begin with a recognized theory and be compiled during the research process based on the data gathered. Theories that are suited to the study problem are developed in the first type, and existing theories are verified in the field to see whether they are acceptable and if they need to be corrected or even rejected. The strategy used in this research is a theoretical study approach that investigates a topic with specific boundaries using in-depth primary and secondary data collection, as well as a variety of real-world sources of information. This research is time and place limited, and the cases studied are individuals, one group, one organization, one program of activities, events, activities, and so on. The goal is to get a comprehensive and detailed description of an entity.

\section{RESULT AND DISCUSSION}

\section{Analysis of interaction between of Varieties and Seed Number on Rice Growth}

Statistical approaches are required to analyze rice plant types with a high number of superior seeds in order to extract the primary components that can maintain the majority of the information in the original data. Using only a few primary components, principal components are able to retain the majority of the information measured using total variance. Principal component analysis is also regarded as a method of estimating data from large dimensions to smaller dimensions by optimizing specific indexes (Adnyana, 2016). Rice is the fruit of the rice plant (Oryza sativa L.), which is derived from grass plants (Gramineae). Rice is classified into three eco-geographical groups: Indica, Japonica, and Javanica. Indica rice is grown in tropical Asia, Japonica rice is grown in the subtropics, and Javanica rice is grown in Indonesia. Plant morphology, leaves, stems, grain, shedding, and other characteristics distinguish the three groups.

In this study, we looked at two types of rice plants: Ciherang and Mekongga. The statistical examination of interactions between Mekongga rice types revealed that it is also a cross between A2970 strain rice from Arkansas, United States of America, and IR 64, a widely planted variety in Indonesia. The planting age of Mekongga is only 116 to 125 days. The plant is physically upright, with a plant height ranging from 91 to $106 \mathrm{~cm}$. Tillers with 13-16 stems are productive. Because the amylose content reaches $23 \%$, the grain is long and slender with a fluffier rice-flavored texture. Because 1000 grains of Mekongga grain weigh 28 grams, the potential yield of this variety is 8.4 tons per hectare if the cultivation technique is correct (Adnyana, 2016). The number of seeds per clump of a variety had no effect on panicle length, grain weight per panicle, grain weight per plot, or grain yield per hectare. As the table below shows, the height of rice plants differs little depending on the number of seeds per plant. 

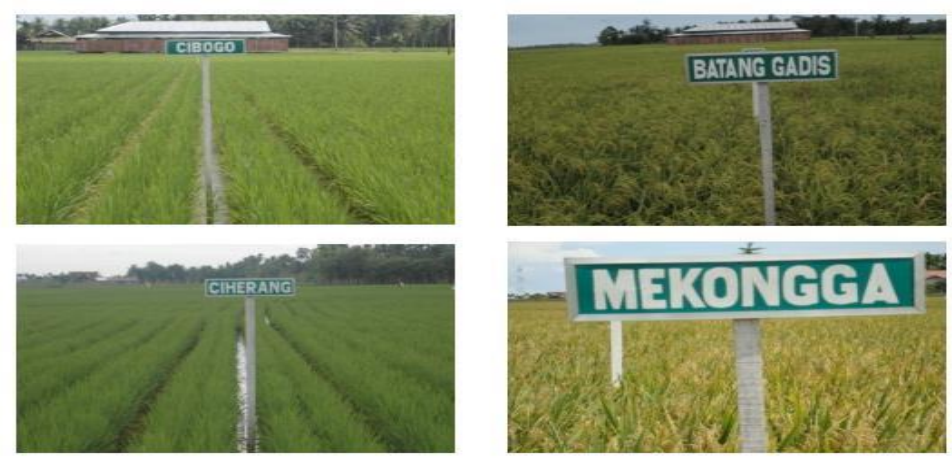

Fig 2. High yielding rice varieties: Cibogo, Batang Gadis, Ciherang and Mekongga

The required seed for a 1 ha planting area is $20 \mathrm{~kg}$. The pithy seeds (which sink) are rinsed and then soaked in water for 24 hours. It is also soaked in sacks for 48 hours, and the humidity is maintained by wetting the sacks with water. For hybrid seeds that have been directly soaked in water and then ripened. The nursery area should be $400 \mathrm{~m} 2 /$ ha (4\% of the planted area). The nursery beds are 1.0-1.2 m wide and filled with a mixture of manure, sawdust, and ash weighing up to $2 \mathrm{~kg} / \mathrm{m} 2$. This addition makes it easier to remove rice seedlings, reducing root damage. A trench as deep as $25-30 \mathrm{~cm}$ was dug between the beds.

\begin{tabular}{|c|c|c|c|c|}
\hline \multirow{2}{*}{ Treatment } & \multicolumn{3}{|c|}{ SEEDS NUMBER } & \multirow{2}{*}{ Average } \\
\hline & 2 Stem clump ${ }^{-1}\left(\mathrm{~J}_{1}\right)$ & 4 Stem clump ${ }^{-1}\left(\mathrm{~J}_{2}\right)$ & 6 Stem clump ${ }^{-1}\left(\mathrm{~J}_{3}\right)$ & \\
\hline Ciherang $\left(\mathrm{V}_{1}\right)$ & 79,69 & 76,43 & 72,20 & 76,10 \\
\hline Mekungga $\left(\mathrm{V}_{2}\right)$ & 77,20 & 79,23 & 73,47 & 76,63 \\
\hline Average & $78,44^{\alpha}$ & $77,83^{\alpha}$ & $72,84^{\alpha}$ & \\
\hline NPBNJ $\alpha=0,05$ & \multicolumn{4}{|c|}{7,68} \\
\hline
\end{tabular}

Table1. Number of seeds per panicle of rice plants (grains)

The interaction between varieties and the number of seeds per clump was observed in the treatment of the Ciherang variety (v1) with the number of seeds 6 stems per clump (j3) having a significant effect on panicle length of rice plants $(24.93 \mathrm{~cm})$, grain weight per panicle (4.10 grams), weight of grain per plot (38.46 kilograms), and grain yield per hectare (8.14 tons per hectare). This shows that the Ciherang variety is more likely than the Mekongga type to generate superior growth and yields. Similarly, when comparing the yield and grain weight of 6 seeds per clump to 2 and 4 stems per clump, the yield and grain weight of 6 seeds per clump produced the greatest results due to the huge number of tillers created by the usage of 6 seeds per clump, resulting in a high production.

Thus, the interaction between varieties and the number of seeds per clump had a significant effect on plant height, number of tillers per clump, productive tillers per clump, filled grain per panicle, and panicle density. This demonstrates that the amounts of seeds used, as well as the variety of seeds utilized, have no effect on the vegetative and generative growth of rice plants. Besides that, internal and environmental factors influence growth and yield. The internal factor in question is the genetic factor itself, namely the properties contained in the planting material/seed used in plant cultivation, whereas 
environmental factors are those that surround the plant itself, which are usually referred to as abiotic factors (climate, soil) and environmental factors.

\section{Rice Yield as Sustainable Agricultural Cultivation}

For rice-field cultivation, combine high-yielding varieties like Ciherang with 6 seeds per clump and Mekongga varieties with 2 seeds per clump. The Efforts improve rice production and productivity through the development of new high-yielding varieties and the jajar legowo planting system. Superior varieties, according to (Senewe \& Alfons, 2011), are the main technological components that contribute 56.1 percent to increasing national rice production.

One of the P2BN program's implementations is the use of superior varieties (Sudrajat, 2017). The jajar legowo planting system is one of the components of PTT in lowland rice, and it has the following advantages over other planting systems: 1) there is more open space between the two groups of rows of plants, which allows more sunlight to enter each clump of rice plants, increasing activities that have an impact on productivity. 2) This crop system makes farm management easier for farmers by providing additional fertilization, weeding, pest and disease control, and other services (spraying). It is also less difficult. 3) Increase the number of plants on both sides of each legowo set, resulting in increased crop productivity. 4) This crop system is also being developed for the development of the rice-fish production system (mina padi) or parlebek (a combination of rice, fish, and duck), 5) increasing rice productivity by up to 10-15\%. (Smith \& McDonald, 1998)

As a result, as stated in Article 1 of the Law on Sustainable Agriculture, the Sustainable Agricultural Cultivation System is the management of living natural resources in the production of agricultural commodities in order to better and sustainably meet human needs while preserving the environment. The term "sustainability" has several meanings in the context of agricultural business development. Specifically, (1) sustainability as a development strategy, (2) sustainability as the ability to achieve goals, and (3) sustainability as an effort to continue an activity (Hansen, 1996). In terms of target achievement, a sustainable agricultural business system implies that the system must be able to: (1) maintain or improve environmental quality, (2) be able to provide social and economic incentives for all actors in the production system, and (3) be able to create enough products so that every citizen has access to them. (Smith \& McDonald, 1998). Thus, sustainable cultivation serves two purposes: the first is to improve the quality of the environment and agriculture, and the second is to provide social and economic conditions for the community to produce input and output trends of sustainable products.

\section{Sustainability as an Approach}

The impact of very intensive agricultural business development has been on decreasing the sustainability of nonrenewable resources, soil degradation, negative externalities of chemical input use on health and the environment, unequal benefits, lowering the quality and ability of food selfsufficiency, and the safety of agricultural workers. This situation has arisen as a result of the use of conventional agricultural development approaches, which are not always sustainable. Alternatives are frequently associated with identifying approaches that reflect the goal of promoting more appropriate alternatives to conventional farming systems (O’Connell, 1992). Sustainable Agricultural Cultivation As an internal approach, one of the approaches used is one with benefits and drawbacks. Here are some of the benefits and drawbacks of the commodity approach. Methods of approaching: 1. the technology available to farmers to help them overcome production constraints or problems is more appropriate. as 
a result of which the dissemination process is relatively simple 2. Agricultural extension is more efficient and effective to implement because input needs and output management are usually well coordinated. 3. It is possible to create a well-developed innovation system that connects research, extension, farmer, and marketing institutions,

Meanwhile, the Commodity Shortages are 1. Farmers' interests outside of the government's main commodities are receiving less attention. 2. Activities related to specific problems run smoothly if farmers are able to understand them. However, if there is a difference of interest, a conflict arises that is usually difficult to resolve. 3. Agricultural assistance and consulting services tend to consult and provide services for various issues developed by farmers. 4. There may be potential conflicts if other parties want to produce other commodities. Farmers may suffer as a result of this disagreement in numerous circumstances. 5. Commodity development that focuses too much on one or a few key commodities may result in agricultural resources being underutilized to their full potential.

The trend of rice cultivation input and output can be used to examine a sustainable system using this approach (SVR). Where the output is falling, staying the same, or rising. If the output falls, the input becomes indideterminant; if the output remains constant, the input (input) becomes sustainable, and superior rice production can be used as a sustainable agricultural system. Meanwhile, if the output remains constant, falling and steady inputs can be sustained, whereas growing inputs cannot. Similarly, when output rises, input falls and remains constant in order to be sustainable, but the rise in production becomes indideterminant. As shown in the table below.

\begin{tabular}{llll}
\hline \multirow{2}{*}{ Result } & \multicolumn{2}{c}{ Input } \\
\cline { 2 - 4 } & Down & Constant & Up \\
\hline \multirow{2}{*}{ Down } & Indeterminan & No Sustainable & No Sustainable \\
Constant & Sustainable & Sustainable & No Sustainable \\
Up & Sustainable & Sustainable & Indeterminan \\
\hline
\end{tabular}

Table 2. Sustainability of the agricultural business system based on input and output trends

In addition to the commodity approach resulting from rice cultivation, the concept of conventional agriculture is proposed as an attempt to explain and justify alternative approaches in agricultural development. The conventional agricultural approach in sustainable agriculture has several indicators, including: (1) capital intensive, (2) large scale, (3) Monoculture cultivation is heavily laden with agricultural mechanization, (4) agrochemical inputs are heavily laden with imported raw materials (fertilizers, pesticides, herbicides, etc.), and (5) highly intensive production systems have further encouraged agricultural systems' reliance on external inputs (Farm, 2010). Without realizing it, conditions like this have formed a paradigm that is building agricultural resilience behind the system's fragility. The approach is shown in the table below as an alternative to the traditional strategy in rice farming development. 


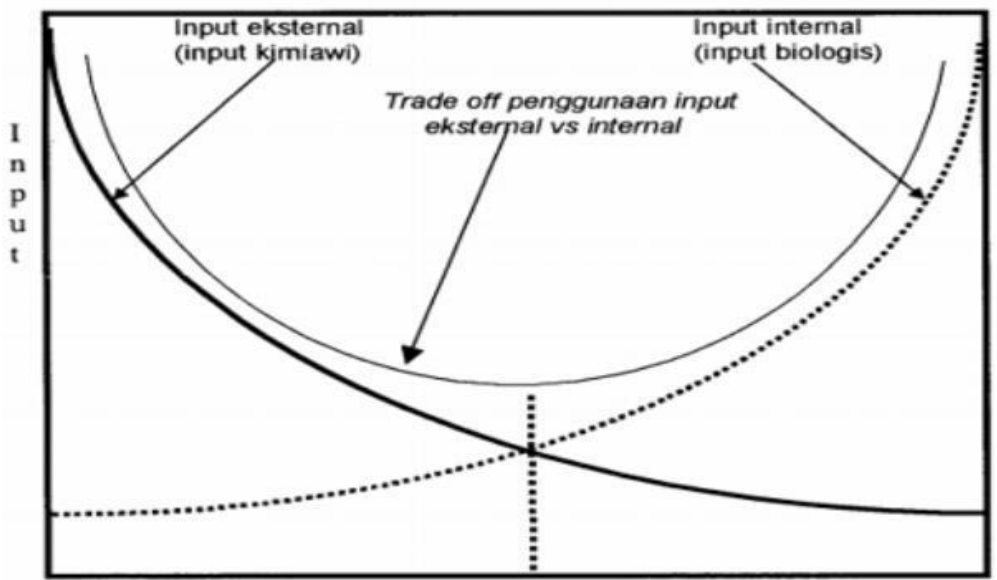

Table 3. The relationship between the level of input use and the sustainability of a production system with a conventional approach

\section{Sustainability as a Strategy}

Sustainable agriculture within the context of human development, which relies on improving the quality and competency of human resources, will be the agricultural development paradigm of the future. According to Gold in Mardikanto, in order to achieve sustainable agriculture, three goals must be combined (Hansen, 1996). Specifically, securing the environment, benefiting and improving farmer welfare, beginning with planning, implementation, monitoring, and utilization of development results. Sustainability is frequently related with enhancing the efficiency of the use of external inputs from chemicals as a strategy in the development of agricultural business systems, such artificial fertilizers, insecticides, and herbicides (Haileslassie et al., 2016). Superior rice plant productivity and sustainable rice cultivation are the outcomes of this strategy.

According to (Smith \& McDonald, 1998), an agricultural and employment-focused economic development strategy necessitates at least three basic complementary elements. First, speeding output growth using technological, institutional, and price incentives designed expressly to boost smallholder productivity. Second, an increase in domestic demand for agricultural output as a result of a development strategy focused on job creation. Third, labor-intensive (non-agricultural) rural area development activities that will directly and indirectly support and support the agricultural sector.

Thus, the right business partnership strategy to encourage the development of agribusiness in rural areas, namely business partnerships through vertical consolidation, can ensure sustainability. Small-scale farming is consolidated in a partnership business by an agro-industry or marketing business to form a unit of agricultural industry (agro-industry). The partnership pattern is founded on all parties' recognition that they need each other and can only grow together, thus it must be implemented according to the principles of transparency, fairness, and agreement compliance. A basic strategy for developing agribusiness in rural areas is the establishment of agro-industry units. As an implementation of the concept of developing an organized rural area, the development of agro-industrial units is an appropriate operational strategy (agropolitan). Because the market for ideas is imperfect and there is a knowledge gap, the development of agro-industry must be aided by the government's active involvement as an honest, fair, and wise starter, mediator, and advisor, facilitator, protector and 
regulator.Basic Agribusiness Development Strategies include the following: 1) The agropolitan approach to agribusiness development is consistent with the implementation of regional autonomy; 2) A community-based approach to agribusiness development with the goal of program effectiveness and implementation; 3) Interactive development of agribusiness systems and businesses in the context of increasing management effectiveness and agricultural commodity competitiveness; and 4) Policy strategy as a facilitating factor for agribusiness development at the national and regional levels.

According to the explanation above, rice yields as sustainable cultivation can be carried out in two systems, the first by implementing a downward community economic development strategy, namely rural areas developed based on the main superior zoning, which produces raw materials for agro-industry development in urban areas.

\section{CONCLUTION}

Analysis of the Interaction between Varieties and Number of Seeds on Rice Growth Using the Ciherang variety combined with the number of seeds 6 stems per clump, it is recommended to use the number of seeds 2 stems per clump when using the Mekongga variety. The Efforts increase rice yield and productivity through the development of superior varieties and the rowing legowo planting system. The findings of the second study, Rice Plants as Sustainable Agriculture via Cultivation and Conventional Approaches, can be applied in a variety of agricultural areas throughout Indonesia. A business partnership through vertical consolidation is formed by using the appropriate business partnership strategy to encourage the development of agribusiness in rural areas. Small-scale farming is consolidated in a partnership business by an agro-industry or marketing business to form a unit of agricultural industry (agro-industry).

\section{REFERENCES}

[1] Abdullah, B., \& Tjokrowidjojo, S. (2005). Perkembangan dan prospek perakitan padi tipe baru di indonesia. 9, 1-9.

[2] Adnyana, M. O. (2016). Pengembangan Sistem Usaha Pertanian Berkelanjutan. Forum Penelitian Agro Ekonomi, 19(2), 38. https://doi.org/10.21082/fae.v19n2.2001.38-49

[3] Aristya, V. E., \& Mada, G. (2019). Pemuliaan Tanaman Partisipatif untuk Meningkatkan Peran Varietas Padi Unggul dalam Mendukung Swasembada Pangan Nasional. 2(1), 26-35.

[4] Delima Napitupulu and Lermansius. (n.d.). Prosiding Seminar Nasional Sains dan Inovasi Teknologi Pertanian. 14, 75-83.

[5] Dewa K.S Swastika1, J. Wargiono2, Soejitno2, dan A. H. (2016). Analisis Kebijakan Peningkatan Produksi Padi Melalui Efisiensi Pemanfaatan Lahan Sawah Di Indonesia. Analisis Kebijakan Pertanian, 5(1), 36-52. https://doi.org/10.21082/akp.v5n1.2007.36-52

[6] Farm, H. V. (2010). Alternative Farming Systems.

[7] Haileslassie, A., Craufurd, P., Thiagarajah, R., Kumar, S., Whitbread, A., Rathor, A., Blummel, M., Ericsson, P., \& Reddy, K. (2016). Empirical evaluation of sustainability of divergent farms in the dryland farming systems of India. Ecological Indicators, 60, 710-723. https://doi.org/10.1016/j.ecolind.2015.08.014

[8] Hansen, J. W. (1996). Is agricultural sustainability a useful concept? Agricultural Systems, 50(2), 117-143. https://doi.org/10.1016/0308-521X(95)00011-S

[9] Hasibuan, R., Levilia, H., \& Wibowo, L. (2013). PERTUMBUHAN JAMUR Beauveria bassiana ( Bals ) Vuill DAN PATOGENISITASNYA TERHADAP HAMA KUTU DAUN KEDELAI ( Aphis glycines Matsumura ). J. Agrotek Tropika, 1(3), 283-288.

[10] Intarti, D. Y., Kurniasari, I., \& Sudjianto, A. (2020). Efektivitas Agen Hayati Beauveria bassiana dalam Menekan Hama Thrips sp. pada Tanaman Cabai Rawit (Capcisum frutescens L.). Agrovigor: Jurnal Agroekoteknologi, 13 (1), 
10-15. https://doi.org/10.21107/agrovigor.v13i1.5621

[11] Jajoo, D., \& Malu, S. K. (2014). Resarch Methodology. A Study of Buying Decision Process in Malls, $49-64$. http://shodhganga.inflibnet.ac.in/bitstream/10603/97412/5/chapter 3.pdf

[12] Jumakir, E. (2015). Technology Implementation for Increasing Rice and Soybean 1-12.

[13] Kustianto, B. (2009). Produktivitas Galur Harapan Padi di Lahan Pasang Surut dan Rawa Lebak. Penelitian Pertanian Tanaman Pangan, 28(1), 34-38.

[14] O’Connell, P. F. (1992). Sustainable agriculture - a valid alternative. Outlook on Agriculture, 21(1), 5-12. https://doi.org/10.1177/003072709202100103

[15] Prasekti, Y. (2015). Analisa Ekonomi Usaha Penangkar Benih Padi Ciherang (di Kelurahan Tamanan Kec. Tulungagung Kab. Tulungagung). Jurnal AGRIBIS, 11(13), 1-11.

[16] Putra Utama1, N. dan I. (2015). No Title. 6(2), 146-156.

[17] Senewe, R. E., \& Alfons, J. B. (2011). Kajian Adaptasi Beberapa Varietas Unggul Baru Padi Sawah Pada Sentra Produksi Padi di Seram Bagian Barat Provinsi Maluku. Jurnal Budidaya Pertanian, 7(2), 60-64.

[18] Smith, C. S., \& McDonald, G. T. (1998). Assessing the sustainability of agriculture at the planning stage. Journal of Environmental Management, 52(1), 15-37. https://doi.org/10.1006/jema.1997.0162

[19] Sudrajat, I. S. (2017). SUSTAINABLE FARMING SYSTEM REVIEWED FROM PERSPECTIVE OF KI HADJAR. 6, $1-17$.

[20] Thippeswamy, S., Chandramohan, Y., Madhavilatha, B., Pravalika, K., Zameema Samreen, Bhoomeshwar, K., Vinod, G. and Kalpana, E. (2014). RESEARCH ARTICLE IDENTIFICATION OF RICE ( ORYZA SATIVA L .) VARIETIES FOR PREVENTION OF TYPE II DIABETES * Thippeswamy, S ., Chandramohan , Y., Madhavilatha , B ., Pravalika , K., Zameema Samreen ,. 6(10).

[21] Wahdah, R., \& Langai, B. F. (2015). Keragaman Karakter Varietas Lokal Padi Pasang Surut Kalimantan Selatan. Keragaman Karakter Varietas Lokal Padi Pasang Surut Kalimantan Selatan, 31(3), 158-165. https://doi.org/10.21082/jpptp.v31n3.2012.p158-165

[22] Zurriyati, Y. (2016). Uji Adaptasi Beberapa Varietas Unggul Padi Sawah terhadap Produksi dan Pendapatan Petani di Kabupaten Bintan Provinsi Kepulauan Riau. 175-183. 